\title{
METODE PENENTUAN WAKTU SHOLAT DI MASJID-MASJID KABUPATEN MALANG
}

\author{
Tolha Hasyim Fanani \\ UIN Maulana Malik Ibrahim Malang \\ Email:fananih@yahoo.com
}

\begin{abstract}
Abstrak
Time is very important in human life. Any human activity that is both personal and social, religious or not will be detached from the context of time. Determination of time praying in mosques Malang district already uses advances in science, but has not been followed by all existing mosques. Mosques like this will follow any rule or determination of the time for prayer that is sent to them. And the prayer schedule is usually annual in nature, although there are several mosques that use radio to keep abreast of current prayer time information.

Waktu merupakan sesuatu yang sangat penting dalam kehidupan manusia. Segala kegiatan manusia baik yang bersifat pribadi dan sosial, maupun keagamaan tidak akan terlepas dari konteks waktu. Penentuan waktu shalat di masjid-masjid Kabupaten Malang sudah menggunakan kemajuan ilmu pengetahuan, tetapi belum diikuti oleh seluruh masjid yang ada. Masjid-masjid seperti ini akan mengikut saja ketentuan atau penentuan waktu shalat yang dikirimkan pada mereka. Dan biasanya jadwal waktu shalat tersebut sifatnya tahunan, meskipun ada beberapa masjid yang menggunakan jasa radio untuk mengikuti perkembangan informasi waktu shalat terkini.
\end{abstract}

Kata kunci: Waktu, Ibadah, Masjid Kabupaten Malang.

Penetapan waktu shalat merupakan persoalan yang sangat klasik sejak masa pertumbuhan Islam, dan hal ini sangat menjadi sorotan para pemikir muslim. Karena permasalahan ini sangat erat kaitannya dengan masalah ibadah. Menurut syariat Islam, praktik shalat harus sesuai dengan segala petunjuk tata cara Rasulullah SAW sebagai figur pengejawantahan perintah Allah. Rasulullah SAW bersabda, "Shalatlah kalian sesuai dengan apa yang kalian lihat aku mempraktikkannya". ${ }^{1}$

Dalam menentukan waktu shalat lima waktu, Rasulullah SAW pernah bersabda: "Waktu Dhuhur itu dimulai dari tergelincirnya matahari tepat di atas bayang benda sampai bayang benda sama panjangnya dengan benda tersebut. Waktu Ashar dimulai panjang bayang sama dengan bendanya sampai tenggelamnya matahari. Waktu maghrib dimulai dari tengelamnya matahari atau munculnya mega merah sampai hilangnya mega merah. Waktu isya' mulai dari hilangnya mega merah sampai tiba waktu shubuh. Waktu shubuh dimulai sejak munculnya fajar shodiq sampai munculnya matahari kembali” (H.R. Muslim).

http://www.angelfire.compro/sembahyang. (Diakses pada tanggal 1 Juli 2010, pukul $12.10 \mathrm{WIB}$ )
Para ahli fiqh memulai dengan shalat Dzuhur, karena ia merupakan shalat pertama yang diperintahkan. Kemudian setelah itu difardhukan shalat Ashar, kemudian Magrib, lalu Isya' dan kemudian shalat shubuh secara tertib. ${ }^{2}$ Para ulama madzhab juga sepakat bahwa shalat itu tidak boleh didirikan sebelum masuk waktunya, dan juga sepakat apabila matahari telah tergelincir berarti waktu Dzuhur telah masuk, hanya mereka berbeda pendapat tentang batas ketentuan waktu ini dan sampai kapan waktu shalat itu berakhir.

Dari sini muncul beberapa golongan dalam upaya penentuan shalat yang menggunakan metode hisab dan metode rukyat. ${ }^{3}$ Praktik hisab dan rukyat dalam kaitanya dengan ibadah harian yang diaplikasikan untuk penentuan awal waktu shalat dalam sehari semalam tidak boleh dijalankan sembarang waktu tanpa adanya alasan yang dibenarkan oleh syara'. Praktik ini berguna untuk mencari keputusan yang meyakinkan berdasarkan penentuan hal-hal tersebut karena masih

\footnotetext{
2 Muhammad Jawad Mugniyah Figh Lima Madzhab. (Jakarta: Dar al-Jawad. 2006) h. 73.

3 Ahmad Izudin Fiqih Hisab Rukyah, Menyatukan NU Dan Muhamadiah Dalam Penentuan Awal Ramadhan Syawal Dan Dzulhijah. (Jakarta Erlangga. 2007) h. 5.
} 
banyak orang berbeda pendapat dalam menentukan caranya.

\section{Metode Penelitian}

Jenis penelitian yang digunakan dalam penelitian ini adalah penelitian sosiologis karena penelitian ini dilakukan di daerah tertentu. ${ }^{4}$ Terkait dengan jenis penelitian ini, maka dapat digolongkan ke dalam penelitian deskriptif. Tujuan dari penelitian deskriptif ini adalah untuk membuat pecandraan secara sistematis, faktual, dan akurat mengenai faktafakta dan sifat-sifat populasi atau daerah tertentu. ${ }^{5}$

Peneliti menggunakan paradigma interpretif fenomenologis, karena paradigma ini digunakan dalam penelitian kualitatif yang mengarahkan pada peneliti untuk mengetahui cara masuk ke dalam dunia para subyek yang akan diteliti sedemikian rupa. Sehingga dapat memahami kehidupan sehari-hari khususnya saat berinteraksi dengan obyek yang diteliti sesuai dengan realita yang ada di lapangan. ${ }^{6}$

Penelitian ini termasuk penelitian studi kasus kualitatif, dimana peneliti tidak hanya mengumpulkan data dari sisi kuantitasnya saja tetapi juga ingin memperoleh pemahaman yang lebih dalam dibalik fenomena yang berhasil direkam.

Pengumpulan data yang digunakan dalam penelitian ini adalah : Wawancara atau Interview adalah suatu bentuk komunikasi verbal, jadi semacam percakapan, yang bertujuan memperoleh informasi ${ }^{7}$. Pada metode ini peneliti mendata hal-hal yang berkenaan dengan penelitian, dengan cara mengajukan pertanyaan-pertanyaan yang telah dipersiapkan terlebih dahulu dalam suatu daftar pertanyaaan. Wawancara ini dilakukan dengan melibatkan para Ta'mir Masjid dan pihak yang bersangkutan dengan permasalahan ini.

Dalam penelitian ini menggunakan metode dokumentasi dan sumber data yang digunakan adalah sumber data primer. $^{8}$ Data ini diperoleh langsung di lapangan, berupa hasil wawancara dengan orangorang yang berhubungan dalam penelitian ini antara lain Ta'mir Masjid, Kyai atau tokoh masyarakat Kabupaten Malang. Dan data sekunder yaitu sumber data yang sifatnya tambahan sebagai unsur keleng-

\footnotetext{
4 Soerdjono Soekanto Penelitian Hukum Normatif. (Jakarta:PT. Raja Grafindo. 2003) h. 12.

5 Sumadi Suryabrata Metodologi Penelitian. (Jakarta: PT Raja Grafindo Persada. 2005) h. 75.

6 Cik Hasan Bisri Pilar-Pilar penelitian Hukum Islam dan Pranata Sosial. (Jakarta: PT, Raja Grafindo Persada.2004). h. 270.

7 S. Nasution. Metode Research. (Bandung : PT Jemmars. 1991) h. 153.

8 Gabriel Amin Silalahi. Metodologi Penelitian dan Studi Kasus. Sidoarjo: CV. Citramedia, 2003. h. 57.
}

kapan penulisan. ${ }^{9}$. Data sekunder diperoleh dengan menggunakan metode dokumenter di antaranya hasil penelitian.

Metode pengolahan data yang pertama adalah editing. Hal ini diperoleh dari metode penentuan waktu shalat masjid-masjid di kabupaten Malang. Yang kedua classifying. ${ }^{10} \mathrm{Hal}$ ini diperoleh dari metode penentuan waktu shalat masjid-masjid di kabupaten Malang. Tahapan selanjutnya verifying, hal ini dilakukan untuk menguji validitas dari data yang telah terkumpul serta bertujuan untuk mempermudah peneliti dalam menganalisa data. ${ }^{11}$ Suatu proses kegiatan penyederhanaan data ke dalam bentuk tertentu agar lebih mudah dibaca kemudian diinterprestasikan, dari hasil wawancara. Dapat dianalisa dengan teori-teori yang relevan. Concluding, merupakan hasil kesimpulan suatu proses penelitian. ${ }^{12} \mathrm{Di}-$ sinilah puncak dari penelitian ini, kegelisahan dan permasalahan yang disampaikan dalam latar belakang akan segera mendapatkan jawaban.

Dalam analisis data kualitatif, sebenarnya peneliti tidak harus menutup diri terhadap kemungkinan penggunaan data kuantitatif, karena data ini sebenarnya bermanfaat bagi pengembangan analisis data kualitatif itu sendiri. ${ }^{13}$ Pada dasarnya analisis data merupakan penguraian data melalui tahapan kategorisasi dan klasifikasi, perbandingan dan pencarian hubungan antar data yang secara spesifik tentang hubungan antar peubah. ${ }^{14}$

Dalam analisis data, peneliti berusaha untuk memecahkan permasalahan yang tertuang dalam rumusan masalah dengan menggunakan analisis data deskriptif kualitatif.

\section{Hasil Dan Pembahasan \\ Hasil}

Nabi Muhammad SAW merupakan Nabi terakhir yang diutuskan oleh Allah SWT untuk membimbing manusia ke arah jalan kebenaran. Tidak seperti umat Nabi-nabi yang lain, umat nabi Muhammad telah diperintahkan untuk mengerjakan sholat 5 waktu setiap hari. Ini merupakan kelebihan dan anugerah Allah

\footnotetext{
9 Saad Ibrahim. Metodologi Penelitian Hukum Islam. Malang, 2002. h. 23.

10 Lexy J. Moleong, (Metode Penelitian Kualitatif, (Bandung: PT Remaja Rosda Karyah. 2010). h. 104-105.

11 Nana sudjana dan Ahwal Kusumah, Proposal penelitian: Di Perguruan Tinggi (Bandung: Sinar Baru Algasindo,2000) h. 85.

12 Nana sudjana dan Ahwal Kusumah. Proposal penelitian. h. 89.

13 Burhan Bungin Analisis Data Penelitian kualitatif. (Jakarta: PT, Raja Grafindo Persada. 2003) h. 83.

14 Cik Hasan Bisri. Penuntun Penyusunan Rencana Penelitian Dan Penulisan Skripsi Bidang Ilmu Agama Islam (Jakarta: PT, Raja Grafindo persada. 2003) h. 66.
} 
SWT terhadap umat nabi Muhammad dimana sholat tersebut akan memberikan perlindungan ketika di hari pembalasan kelak. Dimensi shalat dan penetapan waktu-waktu shalat menjadi pembahasan penting dalam kajian agama Islam.

Berdasarkan observasi yang dilakukan para astronom diketahui bahwa perjalanan harian matahari relatif tetap, maka terbit, tergelincir dan terbenamnya dengan mudah dapat diperhitungkan termasuk kapan matahari itu akan membentuk bayangan suatu benda

sama panjang dengan bendanya juga dapat diperhitungkan untuk setiap hari sepanjang tahun. ${ }^{15}$ Namun

dengan adanya kemajuan ilmu pengetahuan, tanpa melihat posisi matahari, manusia dapat mengetahui kapan datangnya waktu shalat. ${ }^{16}$

Sementara itu, sejak dulu hingga zaman sekarang, dalam perhitungan tanggal dan waktu digunakan kalender. Kalender yang terkenal bagi umat Islam dan berlaku secara universal adalah kalender Masehi yang menggunakan sistem perjalanan matahari (solar system) dan kalender Hijriyyah yang menggunakan sistem perjalanan bulan (lunar system). Di antara kedua kalender tersebut terdapat selisih 11 hari dalam satu tahunnya. Pada kalender Masehi, rata-rata perjalanan matahari dalam satu tahun menempuh waktu 365,25 hari. Sedangkan pada kalender Hijriyah ratarata perjalanan bulan dalam satu tahunnya menempuh waktu 354,37 hari. ${ }^{17}$

Selisih perhitungan tahun ini ternyata sudah diisyaratkan oleh Allah SWT jauh sebelum kedua kalender ini ditetapkan oleh manusia. Dapat dicermati dalam surat al-Kahfi : 25;

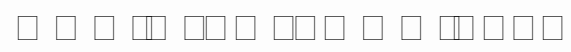

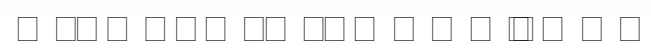 $\square \square \square \square \square \square \square \square$ \\ “Dan mereka tinggal dalam gua mereka tiga}

ratus tahun dan ditambah sembilan tahun (lagi)”.

Sebagaimana telah diketahui bahwa shalat merupakan rukun Islam yang ke lima. Para ulama' sepakat bahwa menunaikan shalat lima waktu hukumnya wajib. Walaupun al-Qur'an tidak menjelaskan secara terperinci, namun waktu-waktu shalat dijelaskan dalam hadits-hadits Nabi. Adapun dasar-dasar hukum dan ketentuan waktu-waktunya dalam al-Qur'an antara lain:

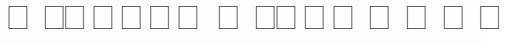 $\square \square \square \square \square \square \square \square \square \square \square$

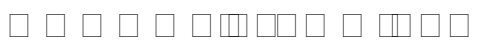

$\square \square \square \square \square \square \square$

" Dan Dirikanlah sembahyang, tunaikanlah zakat, dan taatlah kepada rasul, supaya kamu diberi rahmat" (Al-Qur'an surat al-Nur ayat 56)

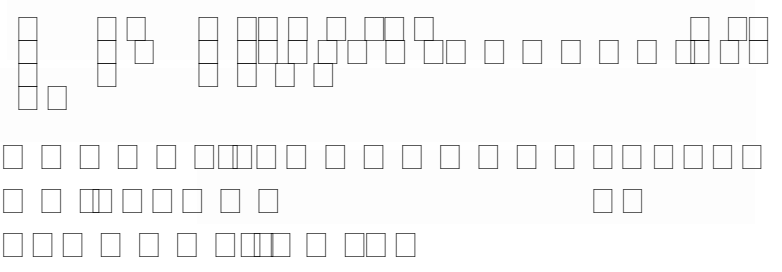

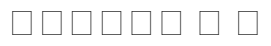 \\ $\square \square \square \square \mathbb{\square} \square \square \square \square$}

“ Maka apabila kamu telah menyelesaikan shalat(mu), ingatlah Allah di waktu berdiri, di waktu duduk dan di waktu berbaring. Kemudian apabila kaти Telah merasa aman, Maka Dirikanlah shalat itu (sebagaimana biasa). Sesungguhnya shalat itu adalah fardhu yang ditentukan waktunya atas orangorang yang beriman". (Al-Qur'an surat an-Nisa' ayat 103)


“Dan Dirikanlah sembahyang itu pada kedua tepi siang (pagi dan petang) dan pada bagian permulaan daripada malam. Sesungguhnya perbuatanperbuatan yang baik itu menghapuskan (dosa) perbuatan-perbuatan yang buruk. Itulah peringatan bagi orang-orang yang ingat". (Al-Qur'an surat Hud ayat 114)

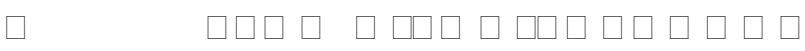

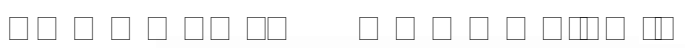 $\square \square \square \square \square$ $\square$

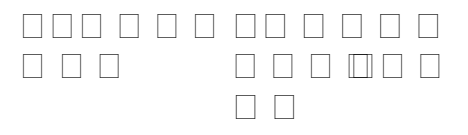

"Dirikanlah shalat dari sesudah matahari tergelincir sampai gelap malam dan (dirikanlah pula shalat) subuh. Sesungguhnya shalat subuh itu disaksikan (oleh malaikat). (Al-Qur'an surat al-Isra' ayat 78)

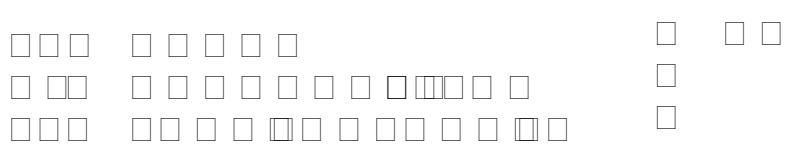


138 Jurisdictie, Jurnal Hukum dan Syariah, Volume 2, Nomor 2, I $\square \square \square$

$\square \square \square$

$\square \square \square \square \square \square \square \square \square \square \square \square \quad \square$

15 Maskufallmu Falaq. (Jakarta: PT. Gaung Persada. 2009) h. 94.

16 Dr. Rinto Anugraha (Peneliti Pascadoktoral 2008-2010 di Kyushu University, Fukuoka, Japan) (Diakses pada Selasa, 15 Sya baan 1431/27 Juli 2010)

17 Moh Murtadho. Ilmu Falak Praktis. (Malang : UIN-Malang Press. 2008) h. 91-92

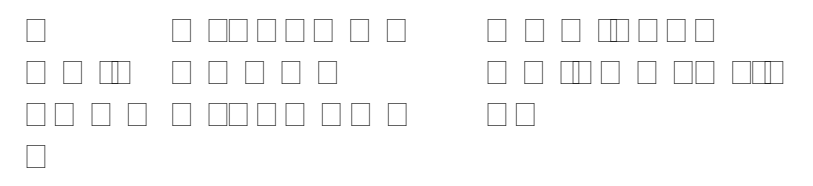




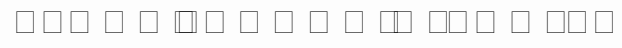

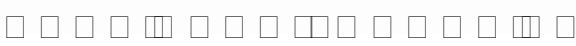

"Sungguh kami (sering) melihat mukamu menengadah ke langit, Maka sungguh kami akan memalingkan kamu ke kiblat yang kaтu sukai. palingkanlah mukamu ke arah Masjidil Haram. dan dimana saja kamu berada, palingkanlah mukamu ke arahnya, dan sesungguhnya orang-orang (Yahudi dan Nasrani) yang diberi Al Kitab (Taurat dan Injil) memang mengetahui, bahwa berpaling ke Masjidil Haram itu adalah benar dari Tuhannya; dan Allah sekali-kali tidak lengah dari apa yang mereka kerjakan." (Al-Qur'an surat Al-Baqarah ayat 144)

Adapun hadits yang berasal dari Nabi Muhammad $\mathrm{SAW}^{18}$, antara lain sebagai berikut:

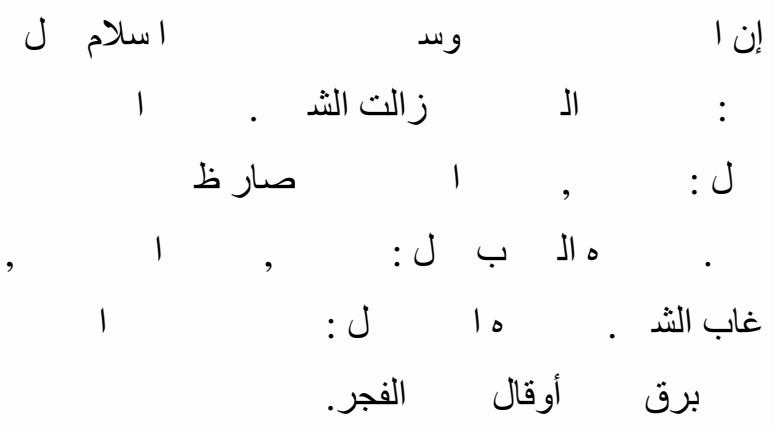

"Bahwasannya Jibril a.s. datang kepada Nabi SAW, lalu berkata kepadanya: Bangun dan bershalatlah, maka Nabi pun bershalat dzuhur ketika telah tergelincir matahari. Kemudian Jibril datang pula kepada Nabi pada waktu ashar, lalu berkata: bangun dan shalatlah, maka Nabi bershalat ketika bayangan segala sesuatu itu menjadi sepanjang dirinya. Kemudian Jibril datang pula kepada Nabi pada waktu maghrib, lalu berkata: Bangun dan bershalatlah maka Nabi bershalat maghib, di waktu telah terbenam matahari. Kemudian Jibril datang lagi pada waktu Isya serta berkata: Bangun dan bershalatlah maka Nabi bershalat Isya di waktu telah hilang mega-mega merah. Kemudian Jibril datang pula pada waktu shubuh, lalu berkata: Bangun dan shalatlah, maka Nabi bershalat shubuh ketika fajar telah cemerlang". (Hadits yang diriwayatkan oleh Imam Ahmad, AnNasa'I, At-Turmudi, dari Jabir ibn Abdullah r.a.)

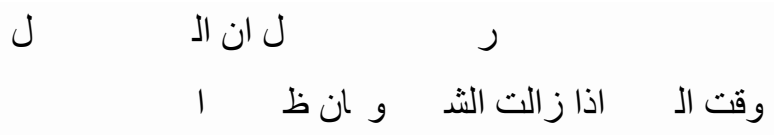

18 Moh Murtadho, Ilmu Falak Praktis. (Malang : UIN-Malang Press. 2008). h. $175-179$

$$
\text { وو }
$$

"Dari Abdullah bin Amar r.a berkata: Sabda Rasulullah SAW: waktu Dzuhur apabila tergelincir matahari, sampai bayang-bayang seseorang sama dengan tingginya, yaitu selama belum datang waktu Ashar. Dan waktu Ashar selama matahari belum menguning. Dan waktu maghrib selama syafaq belum terbenam (mega merah). Dan sampai tengah malam yang pertengahan. Dan waktu Shubuh mulai fajar menyingsing sampai selama matahari belum terbit". (HR.Muslim)

Para ulama' sepakat bahwa salah satu syarat sahnya shalat adalah harus menghadap kiblat, hal ini berdasarkan Nash al-Qur'an dan hadits sebagai berikut:

$$
\text { فول }
$$

"Dari mana saja kamu berangkat, maka palingkanlah wajahmu ke arah masjidil haram”.

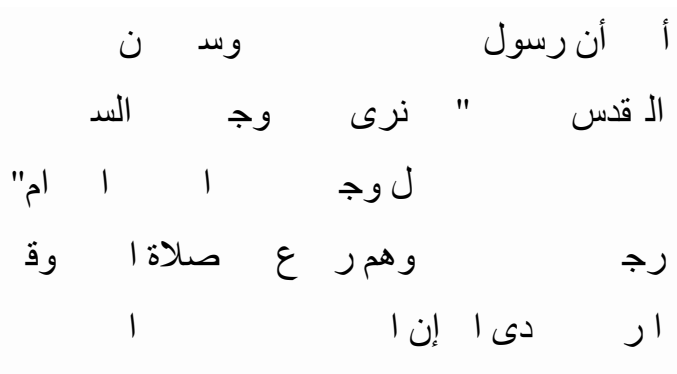

"Dari Sahabat Anas RA sesungguhnya Rasulullah SAW pernah melakukan shalat menghadap Baitul Maqdis, lalu turunlah ayat : sungguh Kami akan memalingkan kamu ke kiblat yang kamu suka, palingkanlah mukamu ke arahnya. Kemudian seorang laki-laki dari Bani Salamah barjalan, sedang mereka semua dalam keadaan ruku' dalam shalat subuh dan mereka telah menyelesaikan satu rakaat lalu ia berkata : ketahuilah sesungguhnya kiblat telah dipindahkan, lalu mereka berpaling menghadap kiblat yang dimaksud".

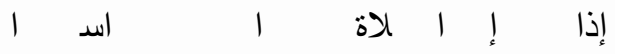

"Bila kamu hendak shalat maka sempurnakanlah wudlu' lalu menghadaplah ke kiblat kemudian bertakbirlah".

Selain hadits diatas ada juga hadits yang diriwayatkan dari Abdullah bin Mas'ud RA, ia berkata :

Artinya: Barangsiapa suka bertemu Allah dalam 
keadaan muslim, maka peliharalah shalat-shalat ini begitu terdengar seruan adzan. Sesungguhnya Allah telah mensyari'atkan kepada Nabi kalian Sunnahsunnah dan petunjuk. Jika kalian mengerjakannya di rumah sebagaimana yang dikerjakan oleh orangorang yang tertinggal (yaitu kaum munafik), sungguh kalian telah meninggalkan Sunnah Nabi kalian. Jika kalian meninggalkannya berarti kalian telah tersesat. Tidaklah seseorang itu bersuci dengan sebaik-baiknya, lalu berangkat ke salah satu masjid, melainkan Allah tulis baginya pada setiap langkahnya satu kebaikan, diangkat derajatnya, dan dihapus darinya satu kesalahan. Dan sungguh kita telah melihatnya. Tidak ada yang tertinggal kecuali seorang munafik yang jelas kemunafikannya. Sungguh salah seorang di antara kami ada yang dipapah oleh dua orang, lalu didirikan dalam shaf," (HR Muslim 654 257). ${ }^{19}$

Bila akan melakukan shalat dengan batasan waktu sesuai dengan bunyi teks hadits di atas maka kita akan mengalami banyak kesulitan, misalnya tiap akan melakukan shalat Ashar maka setiap itu pula membawa tongkat untuk diukur tinggi bayangbayangnya,untuk waktu Maghrib harus mengetahui apakah matahari sudah terbenam atau belum. Demikian juga untuk Isya', Shubuh, Dzuhur setiap itu pula akan melihat awan, fajar dan matahari.

Hisab menurut bahasa berarti hitungan, perhitungan, ${ }^{20}$ arithmetic (ilmu hitung), reckoning (perhitungan), calculus (hitung), computation (perhitungan), calculation (penaksiran). ${ }^{21}$ Sementara itu menurut istilah, hisab adalah perhitungan benda-benda langit untuk mengetahui kedudukannya pada suatu saat yang diinginkan. Maka, apabila hisab ini dikhususkan penggunaannya pada hisab waktu, maka yang dimaksudkan adalah menentukan kedudukan matahari sehingga dapat diketahui kedudukan matahari pada bola langit di saat-saat tertentu.

Perjalanan matahari dari Timur ke arah Barat itu selalu mencapai titik kulminasi yang disebut tengah hari, karena memang menjadi batas seperdua dari siang hari. Waktu yang ditempuh oleh matahari dari titik kulminasi ke titik kulminasi itu lagi disebut sehari matahari yang terbagi menjadi 2 kali 12 jam. Jadi titik kulminasi adalah titik tertinggi yang dicapai matahari

\footnotetext{
19 Syaikh Salim bin 'Iedal-Hilali Al-Manaahisy Syar'iyyah fii Shahiihis Sunnah an-Nabawiyyah atau Ensiklopedi Larangan menurut Al-Qur'an dan As-Sunnah, terj. Abu Ihsan al-Atsari. (Pustaka Imam Syafi'i. 2006) h. 1/475-477.

20 Ahmad Warson Munawwir Al-Munawwir kamus Arab Indonesia. (Yogyakarta: PP “Al-Munawwir” Krapyak. 1984) h. 282.

21 Hans Wehr. A Dictionary of Modern Written Arabic. (Beirut: Librairie Du Liban. 1980)h. 176.
}

dalam perjalanan hariannya. Lingkaran tempuhan matahari dibagi oleh horizon/ufuk pada dua bagian, yaitu bagian di atas ufuk yang disebut busur siang dan bagian di bawah ufuk yang disebut busur malam.

Perjalanan harian matahari dari Timur ke Barat bukanlah gerak hakiki, melainkan karena perputaran bumi pada porosnya (rotasi) dari Barat ke Timur, sekali putaran penuh sekitar $24 \mathrm{jam}$. Akibat rotasi ini, antara lain adanya perbedaan waktu dan pergantian siang dan malam di bumi. Di samping itu, arah rotasi dari Barat ke Timur mengakibatkan tempat-tempat di bumi bagian Timur mengalami waktu terlebih dahulu. Perbedaan waktu tersebut adalah sekitar 1 jam untuk setiap perbedaan $15^{\circ}$ bujur atau 4 menit untuk setiap $1^{\circ}$ bujur.

Sebelum menghitung waktu shalat disuatu daerah dengan tanggal tertentu, diperlukan datadata sebagai berikut: pertama, meridian Pass (MP);22 sudut waktu matahari awal waktu shalat $(\mathrm{t})$; lintang markaz (P) dan bujur markaz; deklinasi matahari adalah jarak suatu benda langit dari equator yang dihitung berdasarkan panjang lingkaran waktu/lingkaran deklinasi dan benda langit tersebut. Nilai deklinasi matahari terbesar $=-23,5^{\circ}$ (negatif) apabila matahari di selatan ekuator, atau $23,5^{\circ}$ (positif) apabila matahari di utara equator. Perbedaan nilai deklinasi menentukan perbedaan waktu shalat (Tabel I).

\section{Tabel I \\ Daftar Deklinasi}

\begin{tabular}{|lll|}
\multicolumn{1}{|c}{ Tanggal } & \multicolumn{1}{c|}{$\begin{array}{c}\text { Deklinasi } \\
\text { matahari }\end{array}$} & \multicolumn{1}{c|}{ Tanggal } \\
22 Desember & $-23^{\circ} 30^{\prime}$ & 22 Desember \\
21 Januari & $-20^{\circ}$ & 22 Nopember \\
8 Februari & $-15^{\circ}$ & 3 Nopember \\
23 Februari & $-10^{\circ}$ & 20 Oktober \\
8 Maret & $-5^{\circ}$ & 6 Oktober \\
21 Maret & $0^{\circ}$ & 23 September \\
4 April & $+5^{\circ}$ & 10 September \\
16 April & $+10^{\circ}$ & 28 Agustus \\
1 Mei & $+15^{\circ}$ & 12 Agustus \\
23 Mei & $+20^{\circ}$ & 24 Juli \\
21 Juni & $+23^{\circ} 30^{\prime}$ & 21 Juni
\end{tabular}

"Z" adalah jarak "Zenith" dengan benda langit. Data "Z" ini digunakan untuk mencari sudut waktu

\footnotetext{
22 Sriyatin Shadiq. Hisab awal Waktu Sh.at, makalah disampaikan pada Orientasi Tenaga Teknis Hisab Rukyat Tingkat Dasar Direktorat Pembinaan Peradilan Agama Departemen Agama di Wisma YPI Ciawi Bogor pada tanggal 17-21 juni 2003. h. 49-50
} 
matahari. ${ }^{23}$ Dari sudut waktu inilah kemudian dicari awal waktu shalat (Tabel II).

\section{Tabel II}

\section{Data Z dan H Matahari Awal Waktu Shalat}

\begin{tabular}{|lll|}
\multicolumn{1}{|c}{ Waktu } & \multicolumn{1}{c}{ Z Matahari } & \multicolumn{1}{c|}{ H Matahari } \\
Dzuhur & $(\mathrm{q}-\mathrm{d})$ & $90($ nilai $\mathrm{t}=0)$ \\
Ashar & $\tan \mathrm{z}=\tan (\mathrm{q}-\mathrm{d})+1$ & $\begin{array}{l}\text { Cotan } \\
\mathrm{h}=\tan (\mathrm{q}-\mathrm{d})+1\end{array}$ \\
Maghrib & $91^{\circ}$ & $-1^{\circ}$ \\
Isya' & $108^{\circ}$ & $-18^{\circ}$ \\
Shubuh & $110^{\circ}$ & $-20^{\circ}$ \\
Imsak & $112^{\circ} 30^{\prime}$ & $-22^{\circ} 30^{\prime}$ \\
Syuruq & $\left({\left.\text { Subuh }-10^{\mathrm{m}}\right)}^{\circ}\right.$ & $-1^{\circ}$ \\
Dhuha & $85^{\circ} 30^{\prime}$ & $4^{\circ} 30^{\prime}$
\end{tabular}

Di Indonesia ilmu falak juga berkembang pesat. Dalam Ensiklopedi Islam Indonesia dinyatakan bahwa ulama yang pertama terkenal sebagai bapak falak Indonesia adalah Syekh Taher Jalaluddin al-Azhari. Namun, berdasarkan data historis sebenarnya selain Syekh Taher Jalaluddin pada masa itu juga ada tokohtokoh falak yang sangat berpengaruh, seperti Syekh Ahmad Khatib Minangkabau, Syekh Muhammad Arsyad al-Banjari, Ahmad Rifa'i, dan K.H. Sholeh Darat. Selanjutnya perkembangan ilmu falak di Indonesia dipelopori oleh K.H. Ahmad Dahlan dan Jamil Djambek. Kemudian diteruskan oleh anaknya Siraj Dahlan dan Saadoe'ddin Djambek (1330-1398 H/ 1911-1977 M). Diantara murid Saado'eddin yang menjadi tokoh falak adalah H. Abdur Rachim. Beliau adalah salah seorang ahli falak Muhammadiyah yang sangat disegani. ${ }^{24}$

Secara etimologi istilah rukyat berasal dari bahasa arab, yaitu dari kata al-ra' a yang berarti melihat dengan mata, maksudnya adalah melihat dengan mata bugil (langsung), ${ }^{25}$ atau kegiatan ru'yah al-hilal bi alfi'li, yaitu melihat hilâl dengan mata, baik tanpa alat maupun dengan alat. ${ }^{26}$ Maka yang disebut rukyatul hilal adalah kegiatan yang dilakukan oleh seseorang atau sekelompok orang yang melakukan pengamatan secara visual baik menggunakan mata langsung atau-

\footnotetext{
23 Sriyatin Shadiq. Hisab awal Waktu Sh.at, h. 192

24 Fami fachrudin @ isnet. Hisab dan rukyat. (Diakses 22 Juni 2010, pukul 18:10)

25 Muhammad bin Abi Bakar bin Abdillah (tt.) Mukhtar al-Shihah, Juz I, Mesir: al- Amiriyah. h. 97.

26 Pedoman Rukyat dan Hisab Nahdlatul Ulama (Jakarta: Lajnah Falakiyah Pengurus Besar Nahdlatul Ulama, 2006), h. 24.
}

pun dengan bantuan alat terhadap kemunculan hilal. ${ }^{27}$ Dari definisi di atas, maka perlu dipahami apa yang dimaksud dengan matahari terbenam dan apa arti dari ijtimak. Matahari disebut terbenam, apabila ujung piringan atas matahari telah meninggalkan ufuk barat. Sedangkan ijtimak adalah posisi dimana sudut elongasi (jaraknya) bulan terhadap matahari adalah nol derajat. Atau posisi bulan, bumi dan matahari segaris dan apabila di lihat dari bumi, tinggi matahari dan bulan sejajar terhadap ufuk.

Kelebihan dari menggunakan metode hisab dalam menentukan awal bulan hijriyah adalah keefektifan waktu yang terpakai dan ketepatan hasil hisab karena telah didukung dengan data-data astronomis dan kaidah-kaidah ilmiyah. Selain itu banyaknya macam dalam metode hisab mengakibatkan berbeda juga hasilnya, antara lain hisab urfi dengan hasil hisab modern atau kontemporer.

Adapun kekurangan dalam menentukan awal bulan hijriyah dengan metode rukyat adalah hasil rukyat tidak dapat digunakan untuk menyusun almanak atau kalender tahunan. Begitu pula hasil rukyat sering diragukan karena dipengaruhi unsur subjektif yaitu adanya perbedaan paham antara suatu ormas dengan ormas lain dan metode rukyat juga tergantung dengan kondisi alam.Saat ini rukyat umumnya dilakukan dengan menggunakan hisab terlebih dahulu, terutama untuk menetukan waktu, lokasi dan arah rukyat, rukyat juga dijadikan alat untuk membuktikan hasil hisab. Selain itu, kekurangan rukyat terletak pada mathla yang berlaku di daerah itu saja ataupun berlaku di daerah luar. ${ }^{28}$

Dalam kondisi tertentu, misalnya cuaca sedang buruk, rukyat tidak bisa dilakukan, sedangkan hisab juga tidak luput dari kesalahan perhitungan, jelasnya. Menurutnya, hisab dan rukyat dapat saja dilakukan, apabila penglihatan yang baik (shohihul bashar) dan pengetahuan yang tinggi (shohihul aqli). Selain itu, juga para ahli astronomi dalam menetapkan awal perlu memperhatikan waktu, tempat serta situasi dan kondisi sebelum melakukan hisab dan rukyat.

Ilmu hisab dapat digunakan untuk kesempurnaan memahami, dan mengamalkan nash tentang rukyatul hilal. Rukyah adalah ibu yang melahirkan hisab. Tanpa rukyah hisab akan mandeg, bahkan mustahil adanya. Jadi rukyah itu ilmiah. Itsbat Menteri Agama yang didasarkan pada rukyah dan hisab sebagaimana

\footnotetext{
27 Rukyatul Hilal.org, hisab dan rukyat. (http//: rukyatulhilal.org/hisab-rukyat. html). (Diakses 22 Juni 2010, pukul 18:10)

28 Nasyarudin Syarif, hisab dan rukyat. Majalah risalah edisi syawal $1423 \mathrm{H}$. di akses 15 juli 2010 pkl 11:23 WIB.
} 
rekomendasi MUI mengikat dan berlaku bagi umat Islam secara nasional. ${ }^{29}$

Baru-baru ini misalnya kiblat yang seolah bergeser akibat gempa perlu segera diluruskan. Karena hal itu tidak berdasar logika ilmiah dan berpotensi meresahkan masyarakat. Pergeseran lempeng bumi hanya berpengaruh pada perubahan peta bumi dalam rentang waktu puluhan atau ratusan juta tahun, karenanya tidak akan berdampak signifikan pada perubahan arah kiblat di luar Mekkah dalam rentang peradaban manusia saat ini.Jadi,saat ini tidak ada pergeseran arah kiblat akibat pergeseran lempeng bumi atau gempa. Semua pihak (terutama Kementerian Agama dan MUI) jangan terbawa pada opini yang didasari pada informasi yang keliru. ${ }^{30}$

Masalah ketidakakuratan arah kiblat yang terjadi pada banyak masjid, bukanlah masalah pergeseran arah kiblat, tetapi karena ketidakakuratan pengukuran pada awal pembangunannya. Itu bukan masalah serius dan mudah dikoreksi. Badan Hisab Rukyat (BHR) Kementerian Agama dan BHR Daerah serta kelompok-kelompok peminat hisab rukyat bisa memberikan bantuan penyempurnaan arah kiblat tersebut. Bisa juga dilakukan koreksi masal dengan panduan bayangan matahari pada saat matahari berada di atas Mekkah atau dengan panduan arah kiblat berbasis internet Google Earth/Qiblalocator.

Setelah arah kiblat diketahui, tidak harus bangunannya yang diubah, cukup arah shafnya. Kementerian Agama bersama MUI, BHR, BHRD, dan kelompok-kelompok peminat hisab rukyat bisa melakukan sosialisasi penyempurnaan arah kiblat tersebut. $^{31}$

Oleh karena itu, menurut sebagian ulama' fiqh, sistem hisab pada dasarnya juga berdasarkan pada hadits shahih yang diriwayatkan oleh Imam Bukhari dan Imam Muslim tersebut diatas. Hal ini juga sesuai isyarat al-Qur'an (Yunus:5). Bahkan Imam Taqiyyuddin as-Subki (w. 756) oleh Yusuf al-Qardlawi dinyatakan sebagai ulama' Syafi'iyah yang telah mencapai derajat mujtahid. Menuturkan: "Apabila hisab menafikan kemungkinan rukyat dengan mata, maka wajib bagi hakim menolak kesaksian orang yang

\footnotetext{
29 KH A Ghazalie Masroeri Ketua Pengurus Pusat Lajnah Falakiyah Nahdlatul Ulama (LFNU) Berasal dari paparan lisan yang disampaikan dalam diskusi kriteria awal bulan di Departemen Agama tanggal 18 September 2007 yang dihadiri oleh Menteri Agama, Sekjen Depag, Dirjen Bimas Islam, Direktur Urais, Kasubdit Pembinaan Syariat dan Hisab Rukyat Depag, wakil dari NU, Muhammadiyah, Persis, DDII, para ahli astronomi dari LAPAN, Observatorium Boscha, Planetarium, Bakosurtanal, BMG, Dirjen Pembinaan Peradilan Agama MA, dan MUI.

30 http://t-djamaluddin.spaces.live.com

$31 \mathrm{http} / / / \mathrm{www} . q$ iblalocator.com/
}

mengaku menyaksikan, "ia lalu berargumentasi" karena hisab bersifat eksak sedangkan penyaksian dan berita bersifat dugaan. Dugaan tidak dapat membentur yang eksak, apalagi mengalahkannya." ${ }^{2}$

\section{Pembahasan}

Kabupaten Daerah Tingkat II Malang terletak pada $112^{0} 35 ` 10^{\circ} 90^{\prime \prime}$ sampai $122^{\prime \prime} 57^{\prime} 00^{\prime \prime}$ Bujur Timur $7^{0} 44^{\prime} 55^{\circ} 11^{\prime \prime}$ sampai $8^{0} 26^{\prime} 35^{\circ} 45^{\prime \prime}$ Lintang Selatan, dengan dikelilingi gunung-gunung: Gunung Anjasmoro dan Gunung Arjuno di sebelah Utara, Gunung Bromo dan Gunung Semeru di sebelah Timur, Gunung Kelud di sebelah Barat, Pegunungan Kapur dan Gunung Kawi di sebelah selatan.

Penentuan waktu shalat masjid-masjid di Kabupaten Malang seperti yang dipaparkan oleh salah satu pengurus di Masjid Besar Al-Ihsan Kec. Pakisaji Kabupaten Malang, beliau mengatakan bahwa : "Yo nang kene melok ae nang Masjid Agung Jami' mas, dadi lek Masjid Agung Jami' adzan kene yo melok ae. Wis ono jadwal shalat sing oleh teko Masji Agung Jami' Malang kunu". ${ }^{33}$

Kalau dimasjid al-Ihsan ini tidak mempunyai suatu metode khusus untuk menentukan waktu shalat, dan kami hanya ikut ketentuan yang ada di Masjid Agung Jami' Kota Malang. Misalnya ketika di Masjid Agung Jami' sudah mulai adzan Ashar, kami juga akan melakukan adzan Ashar dan begitu juga dengan shalat-shalat lainnya. Selain itu setiap tahunnya dari pihak pengurus Masjid Agung Jami’ selalu mengirimkan jadwal shalat yang kepada kami tiap tahunnya.

Ketika peneliti menanyakan tentang dimana letak penentuan waktu shalat di Kabupaten Malang, beliau memaparkan bahwa "Masalah iki teko pihak kene gak tau di libatkan mas, pelaksanaane Rukyat. Gak ono undangan opo ngajak langsung teko pihak Masjid Agung Jami'. Yo wis poko'e tiap tahun oleh surat sing isine jadwal waktu shalat, ngunu". ${ }^{34}$

Selama ini kami tidak pernah dilibatkan dalam pelaksanaan rukyatnya. Tidak ada undangan atau ajakan secara langsung dari pihak Masjid Agung Jami’ pada kami. Pokoknya, setiap tahunnya kami pasti mendapat surat yang isinya mengenai jadwal shalatnya.

Hal senada juga dipaparkan oleh Bapak Warsidi selaku ketua II kepengurusan Masjid Nurul Huda Jln. Perusahaan/Jl.RayaTunjung Tirto. Singosari, beliau

\footnotetext{
32 Yusuf al-Qardlawi. Fiqh puasa. ter. Ma'ruf Abdul jalil dkk. (Solo: Era Intermedia. 2001) h. 49

33 Wawancara Masjid Besar Al-Ihsan Kec. Pakis Kabupaten Malang, bersama Bapak Warsim (Rabu, 12 Januari 2011)

34 Wawancara Masjid Besar Al-Ihsan Kec. Pakis Kabupaten Malang, bersama Bapak Warsim (Rabu, 12 Januari 2011)
} 
memaparkan bahwa "Lek masalah penentuan waktu shalat, mriki tumut siaran Radio Andalus mas, dadi selalu tepat waktu. ${ }^{35}$ Dadi mriki mboten tumut masalah rukyat utowo hisab mas masalah penentuan waktu niki, yakin mawon niki sampun tepat waktu".

Dan mengenai penentuan waktu Shalat di masjid Nurul Huda ini sama sekali tidak terlibat secara langsung tentang pengrukyatan waktu shalat, karena kami hanya mengikuti Radio Andalus saja. Jadi tidak perlu repot-repot untuk merukyat atau menghisab tentang penentuan waktu shalat, saya yakin bahwa apa yang disiarkan oleh Radio Andalus itu sudah sesuai dengan yang semestinya.

Lain halnya dengan apa yang dipaparkan oleh pengurus masjid Baiturrohman Kepanjen, mengenai penentuan waktu shalat ini beliau menuturkan bahwa "Tim kami diundang untuk ikut ru'yat di Ngliyep Donomulyo helipet tempat yang bisa helicopter itu mas. Biasanya kami mengirimkan dari departemen hisab, biasanya Gus Aqil dan ketua ta'mir. Hanya beliau saja. Kebetulan Gus Aqil ini juga Gus dari pesantren Miftahul Jannah. Jadi, dari beliaulah kami mendapatkan jadwal waktu shalatnya. Sepertinya, sampean bisa diskusi lebih lanjut nanti untuk pertanyaan tadi Mas. Pokoknya, kami terima jadi, Mas. Masalah penentuan itu kami hanya ikut apa kata pondok saja. Kalaupun tidak ada jadwal, biasanya masjid-masjid di sekitar sini mengikuti masjid-masjid lainnya. Apabila masjid agung adzan, maka akan diikuti oleh masjid-masjid lainnya. Atau sebaliknya, kalau masjid yang lain adzan, maka masjid agung juga ikut adzan. Paparnya". ${ }^{36}$

Beliau mengatakan bahwa dimasjid ini biasanya diundang untuk melakukan Rukyat di Ngliyep Donomulyo, karena ini undangan maka kami mengutus departemen Rukyat untuk ikut memenuhi undangan tersebut, dan biasanya diwakilioleh Gus Aqil yang juga merupakan putranya kyai pondok pesantrren Miftahul Janah dan ketua Ta'mir ikut menemani gus Aqil, dan dari beliaulah kami mendapatkan jadwal tentang pelaksanaan waktu shalat.

Beliau juga menambahkan bahwa pelaksanaan waktu ru'yat itu menjelang hari raya. Yakni pertama sebelum tanggal 1 Ramadhan dan kedua pada tanggal 1 Dzulhijah. Biasanya dua kali dalam satu tahun.

Selanjutnya ketika dikonfirmasi kepada pihak kepengurusan Masjid Agung Jami' Kota Malang, Ustad

\footnotetext{
35 Wawancara, dengan Bapak Warsidi, Masjid Nurul Huda, Singosari Kab. Malang (15 Januari 2011)

36 Wawancara dengan Bapak Rohim Masjid Baitur Rahman Kepanjen Kab. Malang (22 Desember 2010)
}

Kamilun Muhtadin mengatakan bahwa sebenarnya banyak Masjid yang menggunakan rujukan Masjid Agung Jami' ini, seperti halnya yang terjadi di kota Malang sampai pada Kabupaten Malang semuanya terpusat pada Masjid Agung Jami', karena mereka memandang bahwa Masjid Agung Jami' ini sebagai titik kulminatif atau titik temu bagi masjid-masjid lainya baik kota maupun kabupaten. Selain itu Masjid Agung Jami' ini sudah memiliki metode matahari, GPS dan jam matahari dan juga berada pada posisi strategis yakni di tengah-tengah wilayah Malang. ${ }^{37}$

Sebagaimana yang disampaikan oleh bapak Warsidi bahwa sebenarnya tidak ada perbedaan yang mendasar mengenai penentuan waktu shalat di masjid-masjid yang ada di Malang ini semuanya berdasarkan pada penghitungan Hisab Rukyat, hanya saja untuk wilayah Malang sangat jarang ada sebuah masjid yang menentukan secara langsung tentang penentuan waktu shalat ini, semuanya berlandaskan kepada Masjid Agung Jami' kota Malang. ${ }^{38}$

Hal serupa apa yang di tuturkan oleh Bapak Kamilun Muhtadin Ketua Ta'mir Masjid Agung Jami', karena masjid Agung Jami' ini dijadikan sebagai sumber acuan bagi masjid-masjid lain yang berada di Malang, maka sudah barang tentu tidak ada suatu perbedaan yang signifikan tentang penentuan kapan pelaksanaan waktu shalat itu. Dan mungkin yang menjadikan berbeda adalah karena dipengaruhi unsur subyektif yakni adanya perbedaan paham antara suatu ormas dengan ormas lain, aliran satu dengan aliran lain. ${ }^{39}$

Sebagaimana yang disampaikan oleh bapak Rohim selaku pengurus masjid masjid Baitur Rahman Kepanjen. Untuk saat ini belum pernah terjadi perbedaan mengenai ketentuan pelaksanaan waktu shalat di masjid ini, karena seiring berkembangnya zaman semua yang terkait dengan hal ikhwal kegiatan manusia sudah terangkum dalam media-media elektro seperti Radio, Televisi, maupun media massa baik bulletin, majalan maupun Koran, sehingga hal ini sangat membantu tidak terkecuali masalah penentuan waktu shalat, seperti Radio Andalus Malang yang tidak henti-hentinya menyiarkan pelaksanaan adzan shalat Fardhu, penentuan shalat hari raya maupun masalah lainnya. "Perbedaan biasanya hanya terletak pada jam yang digunakan, itupun hanya beberapa detik saja

\footnotetext{
37 Wawancara Bapak Kamilun Muhtadin Masjid Jami' Kota Malang (15 Desember 2011)

38 Wawancara, dengan Bapak Warsidi, Masjid Nurul Huda, Singosari Kab. Malang (15 Januari 2011)

39 Wawancara Bapak Kamilun Muhtadin Masjid Jami' Kota Malang (15 Desember 2010)
} 
kok. Tapi, biasanya, kalau masjid Baiturrahman sudah mengumandangkan adzan, maka masjid-masjid di sekitar sini, juga akan ikut adzan, begitu lho mas. Jadi, perbedaannya itu hanya sepersekian detik atau menit saja mas". ${ }^{40}$

Nah, apa yang dinyatakan oleh ketua II masjid besar Baiturrahman ini, dilengkapi pula dengan pernyataan ketua ta'mir Masjid Agung Jami' Kota Malang, yang menyatakan bahwa : "Saya rasa semua masjid di wilayah Malang, baik itu Kota maupun Kabupaten, menggunakan pedoman yang sama. Artinya, waktunya tidak akan jauh berbeda. Jika di sini sudah adzan, maka seluruh wilayah Malang, saya rasa juga akan ikut mengumandangkan adzan. Di samping itu, kami juga menyiarkan kumandang adzan lewat radio online, dan diikuti oleh radio-radio lainnya yang ada di wilayah Malang dan sekitarnya. Dan media ini efektif sekali, untuk pemberitahuan kepada masyarakat luas bahwa waktu shalat sudah masuk". ${ }^{41}$

Dalam hal ini, masjid Al-Ihsan Pakisaji dan Nurul Huda Singosari menurut saja setiap keputusan atau pedoman yang ditetapkan oleh Masjid Agung Jami'. Terbukti dengan pernyataan Bapak Warsidi bahwa : "Kami biasanya menggunakan jadwal harian yang disiarkan di Radio Andalus FM. Jadi jadwal yang terpampang di sini sudah kami atur mengikuti ketentuan itu". ${ }^{42}$

Ini tidak jauh berbeda dengan pernyataan Bapak Warsim dari masjid Al-Ihsan Pakisaji, beliau memberi keterangan. "Kami sepenuhnya ikut surat edaran dari Masjid Agung Jami' yang diberikan tahunan itu". ${ }^{43}$

Seiring berjalannya waktu penentuan waktu shalat dipengaruhi oleh kemajuan teknologi hal ini erat kaitannya dengan penentuan waktu. Mengenal adanya waktu yang berbeda-beda seperti waktu matahari hakiki, waktu matahari pertengahan, waktu istiwak, waktu daerah dan waktu internasional.

Letak Masjid Agung Jami' yang menjadi pusat dari seluruh masjid yang berada di wilayah Malang menjadikan Masjid Agung Jami' menjadi rujukan utama dalam hal penentuan waktu shalat maupun masalah lainnya. Sehinga ini menjadi tugas yang berat bagi Masjid Agung Jami' untuk terus melakukan perbaikan tidak terkecuali mengenai waktu shalat ini, dan menggunakan alat-alat yang dimiliki demi kepentingan masyarakat banyak.

\footnotetext{
40 Wawancara dengan Bapak Rohim Masjid Baitur Rahman Kepanjen Kab. Malang (22 Desember 2010)

41 Wawancara Bapak Kamilun Muhtadin Masjid Agung Jami’ Kota Malang (15 Desember 2010)

42 Wawancara, dengan Bapak Warsidi, Masjid Nurul Huda, Singosari Kab. Malang (15 Januari 2011)

43 Wawancara Masjid Besar Al-Ihsan Kec. Pakis Kabupaten Malang, bersama Bapak Warsim (Rabu, 12 Januari 2011)
}

Penentuan awal waktu shalat di suatu daerah memang memiliki kebijakan sendiri dalam memakai metode penentuan awal waktu shalat. Malang misalnya, yang diwakili oleh Masjid Agung Jami' sebagai pusat sentral masjid di wilayah Malang, memakai metode perhitungan matahari (jam matahari) dan bencret (bencet) untuk menentukan awal waktu shalat.

Jakarta misalnya, dengan kehati-hatiannya memajukan awal waktu shalat sebanyak 14-18 menit, sedangkan Malang memajukan hanya $1,7^{\circ}$ yaitu sebanyak 6-8 menit saja dari waktu matahari hakiki. Dengan menggunakan metode ini, penentuan awal waktu shalat dapat ditetapkan sepanjang tahun (seumur hidup), makanya banyak jadwal waktu shalat yang terpajang di masjid telah menggunakan jadwal abadi waktu shalat sepanjang masa.

Letak perbedaan secara implisit penulis simpulkan memang tidak ada di Kab. Malang karena semuanya terpusat, akan tetapi perbedaan itu tetap ada yaitu dengan berdasarkan kehati-hatian dari setiap pengurus masjid yang ada, yaitu dengan melebihkan atau mengurangi jadwal waktu shalat yang ada.

Perbedaan dalam sesuatu memang sering terjadi, akan tetapi bila perbedaan itu dijadikan sebagai beban maka akan menjadikan bumerang, namun bila perbedaan ini dianggap sebagai kewajaran,maka hal itu akan memberikan nilai positif bagi yang bersangkutan, seperti dengan penentuan waktu awal shalat.

\section{Kesimpulan Dan Saran}

\section{Kesimpulan}

Penentuan waktu shalat di masjid-masjid Kab. Malang sudah menggunakan kemajuan ilmu pengetahuan sebagaimana yang dimaksud dalam kajian pustaka di atas. Yaitu dengan menggunakan alat berupa GPS, jam matahari, bencret (bencet), dan alatalat lainnya. Akan tetapi memang belum diikuti oleh seluruh masjid yang ada, ini disebabkan karena keuangan dari masjid yang tidak memungkinkan untuk membeli alat-alat tersebut.

Perbedaan penentuan awal waktu shalat sangat dipengaruhi oleh waktu-waktu yang ada, sebagaimana yang penulis kutip di atas. Yaitu adanya waktu yang berbeda-beda seperti waktu matahari hakiki, waktu matahari pertengahan, waktu istiwa', waktu daerah, dan waktu internasional. Selain itu juga dipengaruhi oleh lintang dan bujur daerah tersebut.

Penentuan awal waktu shalat di suatu daerah memang memiliki kebijakan sendiri dalam memakai metode penentuan awal waktu shalat. Malang misalnya, yang diwakili oleh Masjid Jami' sebagai pusat sentral 
masjid di wilayah Malang, memakai metode perhitungan matahari (jam matahari) dan bencret (bencet) untuk menentukan awal waktu shalat.

\section{Saran}

Masjid-masjid di Kabupaten Malang tidak harus terus menerus mengikuti keputusan yang dikeluarkan oleh Masjid Agung Jami', akan tetapi mereka juga harus berusaha untuk meniru atau belajar banyak kepada Masjid Jami' dalam menentukan ketentuan awal

\section{Daftar Pustaka}

Al-Qardlawi, Yusuf. 2001. Fiqh Puasa. ter. Ma'ruf Abdul Jalil dkk. Solo: Era Intermedia.

Anugraha, Rinto. Peneliti Pascadoktoral 2008-2010 di Kyushu University, Fukuoka, Japan

Bisri, Cik Hasan. 2003. Penuntun Penyusunan Rencana Penelitian dan Penulisan Skripsi Bidang Ilmu Agama Islam Jakarta: PT Raja Grafindo Persada.

Bisri, Cik Hasan. 2004. Pilar-Pilar Penelitian Hukum Islam dan Pranata Sosial. Jakarta: PT Raja Grafindo Persada.

Bungin, Burhan. 2003. Analisis Data Penelitian Kualitatif. Jakarta: PT, Raja Grafindo Persada.

Ibrahim, Saad. 2002. Metodologi Penelitian Hukum Islam. Malang: Bayu Media.

Izudin, Ahmad. 2007. Fiqih Hisab Rukyah, Menyatukan NU Dan Muhamadiah Dalam Penentuan Awal Ramadhan Syawal Dan Dzulhijah. Jakarta: Erlangga.

Lajnah Falakiyah Pengurus Besar Nahdlatul Ulama. 2006. Pedoman Rukyat dan Hisab Nahdlatul Ulama. Jakarta: LFNU.

Mugniyah, Muhammad Jawad. 2006. Fiqh Lima Madzhab. Jakarta: Dar al-Jawad.

Munawwir, Ahmad Warson. 1984. Al-Munawwir kamus Arab Indonesia. Yogyakarta: PP “AlMunawwir" Krapyak.

Nana sudjana \& Ahwal Kusumah. 2000. Proposal waktu shalat. Karena tidak menutup kemungkinan masjid Agung Jami' juga melakukan kesalahan.

Keberadaan ta'mir sangat mendukung terutama mengenai penentuan awal waktu shalat, setiap ta'mir diharapkan membentuk departemen atau tim yang bertugas untuk menentukan awal waktu shalat. Karena selama ini masjid-masjid yang tidak menentukan awal waktu sendiri dipengaruhi oleh kurangnya kinerja ta'mir di bidang tersebut.

penelitian: di Perguruan Tinggi. Bandung: Sinar Baru Algasindo.

Salim bin 'Iedal-Hilali, Syaikh. 2006. Al-Manaahisy Syar'iyyah fii Shahiihis Sunnah an-Nabawiyyah atau Ensiklopedi Larangan menurut Al-Qur'an dan As-Sunnah, terj. Abu Ihsan al-Atsari. Pustaka Imam Syafi'i.

Soekanto, Soerdjono. 2003. Penelitian Hukum Normatif. Jakarta: PT. Raja Grafindo Persada.

Suryabrata, Sumadi. 2005. Metodologi Penelitian. Jakarta: PT. Raja Grafindo Persada.

S. Nasution. 1991. Metode Research. Bandung: PT. Jemmars.

Silalahi, Gabriel Amin. 2003. Metodologi Penelitian dan Studi Kasus. Sidoarjo: CV. Citramedia.

Shadiq, Sriyatin. 2003. Hisab awal Waktu Shalat. Makalah disampaikan pada Orientasi Tenaga Teknis Hisab Rukyat Tingkat Dasar Direktorat Pembinaan Peradilan Agama Departemen Agama di Wisma YPI Ciawi Bogor pada tanggal 17-21 Juni.

Syarif, Nasyarudin. Hisab dan Rukyat. Majalah risalah edisi syawal $1423 \mathrm{H}$. di akses 15 juli 2010 pkl 11:23 WIB.

Wehr, Hans. 1980. A Dictionary of Modern Written Arabic. Beirut: Librairie Du Liban.

Rukyatul Hilal.org, hisab dan rukyat. (http//: rukyatulhilal.org/hisab-rukyat.html). 